\title{
Landscape and Geoecological Analysis of Small River Basins Within Nature Protection of Mountain Territories
}

\author{
Kipkeeva P.A. \\ Karachay-Cherkess State University named U.D. Aliyev \\ Karachayevsk, Russia \\ kipkeeva62@mail.ru \\ Ivankova T.V. \\ Institute of Hydraulic Structures Safety \\ Novocherkassk, Russia \\ ivankova.tv@ibgts.ru
}

\author{
Volosukhin Ya.V. \\ Engineering Consulting Center on Hydraulic \\ Structures Safety \\ Novocherkassk, Russia \\ gts@yandex.ru
}

Potapenko Yu.Ya.

North Caucasian Interdepartmental

Stratigraphic Commission

Essentuki, Russia

nupotap@yandex.ru

\author{
Shubayeva N.V. \\ Pyatigorsk State University \\ Pyatigorsk, Russia \\ shubaeva-nataly@yandex.ru
}

\begin{abstract}
Three large rivers of the North Caucasus, namely the Kuban, the Terek and the Kuma play a key role in water supply of adjacent steppe territories of Ciscaucasia. The mass run-off of these rivers is formed within a mountain relief. The river heads of the Kuban and the Kuma are located in the Karachay-Cherkess Republic. The landscape and geoecological research of small river basins of the republic was aimed to collect the information for further nature protection of basin geosystems of the 1-4 orders. The hierarchy, landscape structure and environmental condition of basins typical for six sublatitudinal morphostructures of the Karachay-Cherkessia were studied. The basin landscape structure becomes more complex from lowlands to highlands with the increase of altitudinal belts. Due to the global warming and the reduction of glacier lands, the water content of mountain rivers is decreasing in summer. The maximum anthropogenic load in the conditions of a mountain relief accounts for the bottom of river basins. Despite low density of the population and low level of industrial development in the republic there are local sites of surface-water contamination towards residential, tourist and recreational centers. Priority practical measures on water quality normalization were determined. In terms of their current and intended use, the small basins belong to innovative, restoration, tourist recreation and nature protection types.
\end{abstract}

Keywords - basin geosystems, landscape structures, geoecology, environmental engineering

\section{INTRODUCTION}

By the beginning of the $21^{\text {st }}$ century, the deficiency of fresh water has gained its global reach and hence, environmental and social aspects of sustainable use of water resources were classified as the most urgent. The World Water Forums held every three years since 1997 clearly demonstrate this fact.

The North Caucasus is located in the western part of a steppe belt and on the termination of the desert belt of Eurasia. The northern macroslope of the Greater Caucasus mountain structure with the riverheads of three large rivers - the Kuban, the Terek and the Kuma serves the main water supply of the steppe Ciscaucasia. The mass run-off is defined by a climatic factor, while the water quality - by the ecological state of the environment.

The object of the study were small basins of the Kuban and the Kuma located in the mountain territory of the KarachayCherkess Republic. The water resources of these rivers are described in the monograph [1].

The Kuban River is flowing in sub-meridional direction from high mountain relief, crosses all mid- and high-mountain areas of the Karachay-Cherkess Republic in the north and at the latitude of Cherkessk turns northwest (Fig. 1). Then it flows across the territory of Stavropol, Krasnodar regions and Adygea. The river length is $906 \mathrm{~km}$; the drainage area is 57.9 thousand $\mathrm{km}^{2}$.

The Kuma River originates on the northern slope of the Rocky Ridge, crosses the Cretaceous Ridge and at the latitude of Essentuki flows down to the alluvial sloping outwash plain of Ciscaucasia. The river length is $802 \mathrm{~km}$; the drainage area is 33.5 thousand $\mathrm{km}^{2}$. The Kuma basin includes fragments of five territorial subjects of the Russian Federation - Karachay- 
Cherkessia, Kabardino-Balkaria, Stavropol Territory, Kalmykia and Dagestan.

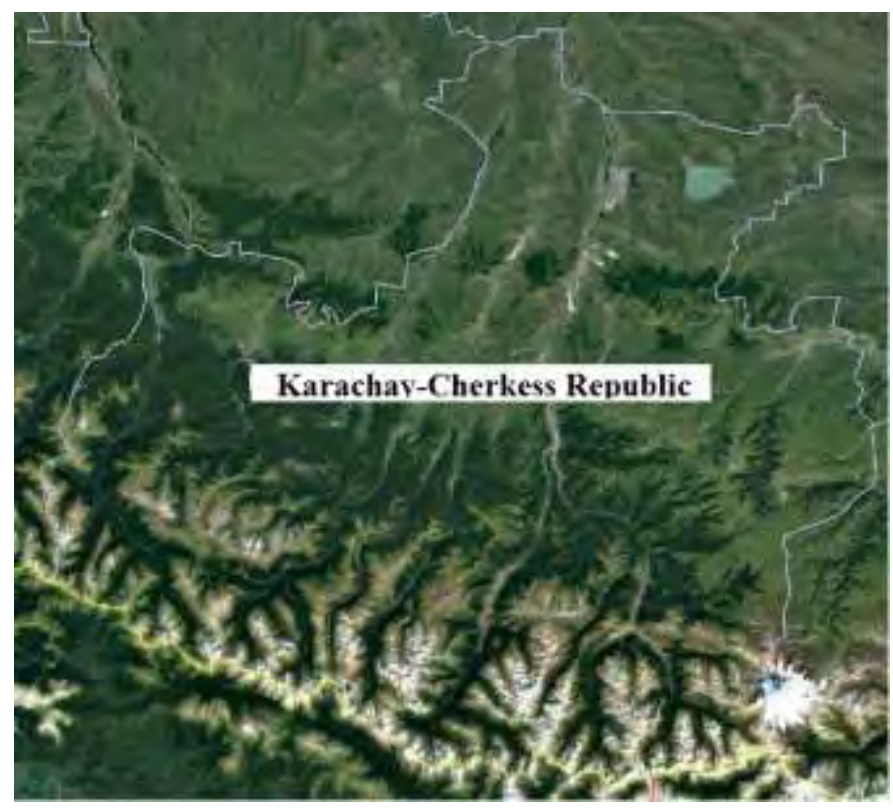

Fig. 1. Space image of Karachay-Cherkessia illusrtates the relief and spatial ratios of mountain-meadow and mountain-forest phytocoenoses.

The narrow northern plain band of the Karachay-Cherkess Republic adjoins the steppe zone of the Ciscaucasian province of the East European Plain, and with a mountain relief the most part of the republic enters the Crimean-Caucasian highland with well-defined altitudinal zonation. With gain in altitude the mountain meadows are replaced by deciduous and coniferous forests, subalpine and alpine meadows and a nival belt. The soils are quite diverse - piedmont chernozems and gray forest-steppe, gray and brown mountain forest, chernozemic mountain-meadow, mountainous subalpine and alpine soils.

The river network of the Kuban plays an important role in irrigation and flood of the Central and Western Ciscaucasia along channels from Ust-Dzhegutinsky and Kuban reservoirs. The Kuma basin includes the Eshkakonsky supplying water to Kislovodsk urban resort.

The relief of the Karachay-Cherkess Republic varies from high mountain alpinotype to mid- and low-mountain structural denudation relief (Fig. 1).

The purpose of the study: 1) to obtain and collect information for environmental engineering of mountain territories (environmental engineering - type of economic activity covering nature protection and environmental management of geosystem basins using water resources [2];2) to define the phases of relative (quasistationary) equilibrium (according to N.F. Reymers [3]) within mountainous natural and anthropogenic systems.

\section{METHODS AND MATERIALS}

The conducted multi-year study (1990-2018) was based on the principles of sustainable development [4] and landscape and basin concept. After the World Commission on Environment and Development [5] in 1987 declared the strategy on sustainable development to recover from the global ecological crisis, there were several options of its interpretation and thus appeared a few new terms describing the environmental condition. An important condition of sustainable development is the compliance with balance and equilibrium between natural and economic, technogenic processes when the environment remains life-friendly for the humankind. There is a variety [3] of terms defining "balance" - natural, anthropogenic, environmental, ecologically viable, componential, territorial, equilibrium within "society-nature (sociological)" system, etc. N.F. Reymers [3] highlights that the balance in natural and anthropogenic systems represents constantly changing, dynamic, and quasistationary state.

The authors conducted the field study to obtain the necessary data on geomorphology, landscapes, lithogenic nature and geoecology of river basins. The authors used the technique of the geoenvironmental analysis of anthropogenic influence on small river reservoirs suggested in [6-9], etc. Spatial parameters and the severity of exposure of the following functional types of anthropogenic load were evaluated: agricultural, industrial, residential, transport, forest and water management, nature protection. Besides, the study included aerial and space photo interpretation, interpretation of geochemical survey results obtained by the divisions of Sevkavgeologiya (North Caucasus Geology), study of river bed evolution, consequences of strong floods, mathematical modeling of flood zones. The complex of methods was used for detailed study of the impact of geological exploration and mining operations on the environment. GIS-technologies (ARCGIS 9.3.1) were used for data processing.

The data obtained by the authors through field studies on typical river basins are partially published in scientific journals $[4,6,13]$.

\section{RESULTS}

The small river basins within the studied territory differ in relief, landscape structure, lithogenic composition and structure. Hence, it is advisable to describe the information in the following sequence: morphostructures, basin geosystems, their landscape structure, condition of landscape components.

\subsection{Morphostructures}

The long geological history of the Greater Caucasus found its expression in the series of morphostructures (MF) that are different in relief pattern and lithogenic composition (structure and conditions of rock bedding). There are six sublatitudinal MF, which width varies from 5 to $30 \mathrm{~km}$, in the KarachayCherkess Republic. The following MF stretch from the south to the north (Fig. 2): Main Range (MR), Front Range (FR), North Jurassic Depression (NJD), Rocky and Pasture (Cretaceous) Ranges (RR+PR) and Pre-Caucasian Plain (PCP).

The MF of the Main Range has a mountain alpinotype relief with a series of glaciers and a large number of rocky exposures of ancient crystalline schists and gneisses containing large massifs of Paleozoic granites. The MF of the 
Front Range is also mountainous but without glacierization; lithogenic content is presented by the assemblage of Paleozoic rocks (Silurian, Devonian, Carbonic, Permian); the Devonian basalts contain several copper-sulphide ore fields. The MF of the North Jurassic Depression is expressed by mid-mountain (up to 2000-2400 m) flat-topped relief developed to high with embedded sedimentation mass of the Lower-Middle Jurassic. The MF of Rocky and Pasture Ranges represent cuestas composed of Upper Jurassic and Cretaceous sandstones and limestones.

\subsection{Basin geosystems}

The basin systems refer to basins of different orders belonging to the basin of a large river or to the basin of the sea (ocean). Over the last 20 years, the majority of publications devoted to the North Caucasus described the idea of "sustainable development", and after the crisis of 2008 - the potential development of tourist and recreation industry. In both cases, the basin concept failed to gain its recognition.

In terms of its morphology, the river network of the Karachay-Cherkess Republic belongs to arborescent, semiarborescent and partially - to feather types (Fig. 2). With regard to sublatitudinal morphostructure the consequent (submeridional) waterways prevail. The morphometric analysis revealed a complex hierarchy of the river network that includes basins of the 1-6 orders.

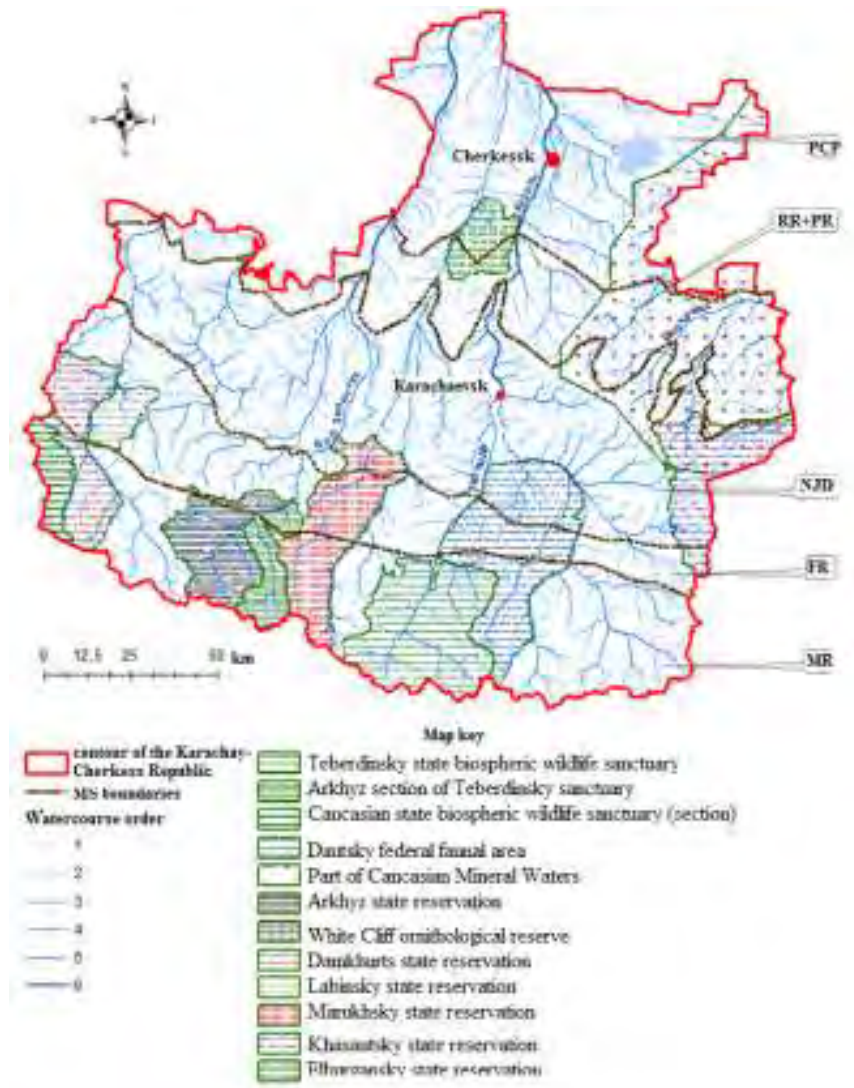

Fig. 2. Map of MF within river networks and protected areas of KarachayCherkessia.
The basins of the 1-2 orders are small areas and have steep bed slopes. They rim larger basins and in most cases do not go beyond certain MF. The basins of larger rivers (4-6 orders) are transboundary, their beds cross all mountain MF and come out to Pre-Caucasian Plain. Hence, there are two types of basin systems within the Karachay-Cherkess Republic - mountain and piedmont basins.

The mountain basins are characterized by actively developed erosion, transfer and accumulation, but their nature and intensity may be different depending on climatic conditions, affiliation with the altitudinal belt, or with any morphostructure. Each basin includes three geomorphological elements: watersheds, slopes and valley bottoms.

In terms of their morphology, the watersheds are divided into four types: battlement sharply-sloped, smooth symmetric, asymmetric (escarps) and flat. The battlement watersheds are typical for the Main (Watershed) Range and separate segments of meridional ridges dividing the river basins. Smooth symmetric and asymmetric watersheds make the most part of the Front and Pasture Ranges. Escarps (Eng.) or cuestas (Fr.) are scarps in a relief of various origin, typical for Rocky and Pasture Ranges. Flat watersheds are developed within the North Jurassic Depression, on northern slopes of the Pasture Range and in foothills.

The slopes usually have convex profiles with the exposure of rocks mostly resistant to weathering. The bottoms of river valleys include the modern riverbed and floodplain, as well as 1) accumulative meso- and microforms: glaciofluvial of trough valley bottoms; fragments of marginal moraines; terminal moraines, 2) erosive and accumulative forms of several stages of valley development - terrace on conjugated slopes.

\subsection{Landscape structure of mountain basin geosystems}

Basins with different morphostructure have individual sets of natural ecosystems and are at different stages of economic development.

The leading landscape researcher of the USSR and Russia A.G. Isachenko [10] developed and proposed a matrix legend for landscapes in highlands on the example of the Teberda River basin located in the central part of the KarachayCherkess Republic. According to him, the altitudinal belts play a role of morphological landscape units within a mountain relief. The horizontal lines of a matrix correspond to altitudinal belts, the vertical columns uniting lines (belts) of one altitudinal layer correspond to landscapes. A.G. Isachenko defined 8 altitudinal belts and 6 landscapes within the Teberda River basin crossing three morphostructures (Main Range, Front Range and North Jurassic Depression) [10]. The authors based their study of landscape structures of basins having different hierarchical orders.

The landscape structure of basins within different MF is quite unique. The MF of the Main and Front Ranges are characterized by up to four-five altitudinal vegetation belts on their slopes: forest, subalpine, alpine, subnival and only the MF of the Main Range - interrupted nival. The set and 
configuration of altitudinal belts define the landscape structure of certain basins.

The coupled analysis of morphostructures and basin geosystems showed that basins of one rank have different size and morphology within various morphostructures.

\subsection{Functional types of anthropogenic load}

The developed territories are usually classified according to the prevailing functional type of anthropogenic load. There are 7 types in the Karachay-Cherkess Republic: agricultural, industrial, residential, transport, forest, water management and nature protection.

The agricultural type is widespread throughout the territory of the Karachay-Cherkess Republic.

The agricultural subtype is mainly developed in the north of the republic where the flat territory is almost completely disturbed and turned into agrolandscape. The livestock subtype leans towards rural settlements. Alpine

meadows are mainly used as summer pastures, and to a lower degree for haymaking.

The industrial type is divided into subtypes - producing and processing. The producing subtype is introduced by a large pit of cement works (limestones of the Pasture Range), several small pits on the production of construction materials. The Uryupsky Mining Complex extracts copper-sulphide ore via the shaft method and processes it into a concentrate at the ore-processing plant. In 2018, half of the 17 processing enterprises were operating in Cherkessk, the others - in other regions of the republic (one or two per region).

\subsection{Transport type}

Currently, the Nevinnomyssk-Cherkessk-Ust-Dzheguta railroad feeder is not too busy. Motor roads are divided into roads with asphalt, gravel, ground coating and field roads. The federal asphalt highway connects Cherkessk with Dombai.

The timber type is represented by three forestry enterprise (Urupsky, Beskessky, Zelenchuksky) that harvest timber and produce joinery goods.

The water management type within the Kuban basin includes Aksautsky, Marukhsky, Ust-Dzhegutinsky and Kuban reservoirs with influent channels and a section of the Great Stavropol Canal. According to their geomorphological feature, the first three are impounding reservoirs, and Kuban lake reservoir. The impounding Eshkakonsky reservoir is within the Kuma basin supplying water to the Kislovodsk urban resort of Stavropol Territory. The impounding reservoirs are silted quickly. Thus, in 2005 the silting of the Ust-Dzhegutinsky reservoir functioning since 1962 made $70 \%$ [1], and in 2018 - nearly $100 \%$.

The disastrous flood of June 2002 caused by heavy rain was a serious challenge for hydraulic structures. During the survey of rivers after flood, we registered an unusually strong riverbed and stream bank erosion lower the dam of the Eshkakonsky reservoir in the Eshkakon riverbed and below its mouth in the Podkumok riverbed. The erosion surpassed flood consequences of the Podkumok and the Kuma rivers. In 2015, the authors participated in the multi-factor study of hydraulic facilities of the Eshkakonsky hydraulic power system conducted by the Institute of Hydraulic Structures Safety (Novocherkassk) under the leadership of Dr.Eng. V.A. Volosukhin. The survey revealed that the reason of this disastrous erosion was the inefficiency of the discharge structure, namely the flood flow damper at water consumption of $210 \mathrm{~m}^{3} / \mathrm{sec}$.

Nature protection type. At present, the majority of territorial subjects of the Russian Federation have their protected areas (PA). These are wildlife areas, more rarely reserves; numerous nature sanctuaries (cliffs, waterfalls, caves, etc.) are usually small.

The PA network of Karachay-Cherkessia includes 2 reserves and 8 wildlife areas (Fig. 2). Despite their large area, the PA role in conservation of the republic is insignificant. These are mainly steep slopes of river valleys hardly suitable for economic use. They were not too much visited even before the protection regime. The comparative study of the vegetation in the heads of the Dauta and Aksauta rivers and the reserved Teberda do not demonstrate any advantages of the protection regime. The number of animals and birds outside the reserve may be higher, which is caused by the abundance of tourists in recreation objects of Dombai and the Teberda urban resort.

The cross-spectrum analysis of natural landscape structures and anthropogenic loads within the considered territory showed the bottoms of the largest river valleys - the Kuban and the Big Zelenchuk mainly exposed to anthropogenic load. This is where different cities, settlements, asphalt roads, and industrial enterprises are located. The rest territory of mid- and high-mountain relief has no resident population. It is used seasonally, during summer - for pastures and forestry.

\subsection{Environmental pollution}

Mountain territories with numerous exposures of bedrocks, including rocks containing ore minerals, are characterized by two types of environmental pollution - natural pollution and anthropogenic pollution.

Natural pollution. The mountain relief with complex and diverse lithogenic composition generated some geological formations containing ore minerals towards the zone of modern erosion processes. This led to natural geochemical anomalies with enhanced concentration of heavy metals. In 1993, P.V. Prokuronov (Sevkavgeologiya) made a 1:1 000000 geo-ecological map. Several crisis situations were defined in some industrially developed areas of Ciscaucasia (for example, Nevinnomyssk). There are some pathogenic geochemical anomalies in the Karachay-Cherkess Republic related to existing ore facilities - Uryupsky Mining Complex, ore field of polymetallic Elbrus field (Paleozoic and more ancient MF foundation of the North Jurassic Depression), with zones of sulfide mineralization in Devonian volcanic rocks within MF of the Front Range. The MF of the Main Range with rare metal mineralization (scheelite) was classified as environmentally friendly territory. 
Large-scale geo-ecological study on environmental impact of exploration and mining operations in Karachay-Cherkessia and Kabardino-Balkaria were conducted in 1990-1993 by one of the authors of the given paper. The studied territory covered all three Paleozoic metallogenic zones known in the Greater Caucasus - Main and Front Ranges and Biychesynskaya (within the MF foundation of the North Jurassic Depression). The complex of methods applied in the field study was supposed to ensure the assessment of environmental potential, stability, environmental damage ratio and pollution. Pasture and recreational depression was thus studied with the use of bioindication methods (lichenological indication, change of mesofauna composition in waterways, etc.). Parameters of mechanical damage caused by exploration works were defined. Soils, bottomset beds, pit bings, tailings dams, underground, mine and adit waters, surface watercourses, shrub and grass vegetation were analyzed to determine qualitative and quantitative characteristics of technogeneous geochemical anomalies.

In general, in comparison with foothills and plain, the environmental condition of a mountain part of the KarachayCherkess Republic was estimated as quite safe, which is explained by lower utilization of the territory.

Anthropogenic pollution. The most intense pollution is caused by industrial, agricultural, residential and recreational activities of the population.

Industrial enterprises manufacturing various equipment, cement plant on the right bank of the Kuban, mining enterprises - Uryupsky mine with its treatment and settling facilities are considered the main sources of industrial pollution. Agricultural pollution in a mountain relief is generally caused by the presence of various farmyards located on river coasts. Residential and recreational pollution affects landscape soil and vegetation, as well as surface waters. Daily waste landfills can be found near many settlements and tourist centers.

The quality of river water is another reason for concern. Let us be limited to the water analyses regarding two rivers performed in the laboratory in the first decade of the current century $[11,12]$. The complex sample analysis of three stations of the Kuban from Uchkulan to Karachayevsk villages allows [12] classifying the Uchkulan water as clean surface runoff (class 1) and downstream - as poorly polluted (class 2 ). Water tests in five stations of the Teberda from Dombai to Karachayevsk [12] revealed the highest impurity below the Dombai village (class 3 "a" - polluted), in other stations the general impurity corresponds to class 2 . The basic pollutants include phenols, manganese, iron, and more rarely - oil products. Continuous phenol content throughout the year clearly indicates the main source of pollution - residential sewage waters $[11,12]$. Meanwhile, the upstream of the Teberd is within the borders of the reserve with the same name, and in the midstream its right coast borders with Dautsky wildlife area (Fig. 2).

\subsection{Water balance of the Kuban River}

The current problem of the water balance of rivers in the vicinity of the Mt. Elbrus shall cover spatial and time aspects.
The annual rainfall in the Kuban basin significantly decreases from the west to the east [1] from 1120-1380 $\mathrm{mm}$ in the basins of the Abin River and the Psekups River (at the height of 500 $\mathrm{m}$ ) up to $480-500 \mathrm{~m}$ in the basin of the Hudes River (right tributary of the Kuban River). It is also known that with the increase in ground height up to $3000-3500 \mathrm{~m}$ the amount of rainfalls increases in mountains. At these heights the rainfall content in the basins of the White, the Big Laba, the Zelenchukov and the Teberda makes $2750-2080 \mathrm{~mm}$, and to the east in the basins of the Uchkulan and the Ullukam it decreases to $1700-1370 \mathrm{~mm}$ [1]. Thus, the rivers near the Mount Elbrus get by 1.5-2 times smaller rainfalls than in the western part of the Kuban basin. According to data of the Teberdinsky reserve, the Teberde River is characterized by continuous reduction of annual rainfalls since 1927 and especially since 1980s [11]. The staff of the Teberdinsky reserve believe that the reduction of water content in anthropogenic activity is caused by the decrease of the forest cover due to salvage cutting of timber, technical damage of floodplains [11]. However, the reduction may also be caused by the degradation of glaciers due to global warming, which is also confirmed by data of meteorological stations of the North Caucasus. Mathematical processing of data obtained from the meteorological station in Essentuki over 80 years showed a clear positive tendency towards temperature increase [13]. The glacier area of the Greater Caucasus is constantly decreasing over the last century. In warm summer months (July and August) the water content in the Kuban tributaries: Ullukama, Uchkulana and Teberda Rivers is maintained due to the most intensive glacial melting. These months were characterized by the overflow and breakthrough of periglacial lakes on the northern slope of the Elbrus leading to destructive mud flows in 1909 and 2006 [14]. In the coming future, further decrease of glacier-fed rivers originating in the mountain part of the Greater Caucasus is expected.

\section{CONCLUSIONS}

The study allows evaluating the condition of mountain basin geosystems of the Kuban and Kuma Rivers as a phase of insignificant transformation of nature at relative (quasistationary) equilibrium, according to N.F. Reymers's classification [3]. There were several objective reasons for this: low population density and industrial development, existence of 10 reserves and wildlife areas occupying $42 \%$ of the territory of the republic (Fig. 2). In 2018, the population density of the Karachay-Cherkess Republic made 32.6 people $/ \mathrm{km}^{2}$. This indicator is higher in the neighboring subjects of the Russian Federation and foreign countries: in Stavropol Territory - by 1.3 , in Dagestan - by 1.8 ; in France by 3.6 ; in Germany - by 6.8 ; in India - by 12.6 times.

In terms of their current and intended use, the small basins of the Karachay-Cherkess Republic belong to innovative (development of new natural objects), restoration (restoration of lost economic infrastructure), tourist recreation and nature protection types.

There is a need for landscape planning of the entire mountain territory based on the program developed by the international team of experts in relation to Russia to preserve the environment of the Greater Caucasus and ensure its sustainable development [15]. The river basins of the $4^{\text {th }}$ order, 
which configuration does not depend on administrative and economic changes, may be used as the minimum territorial units of environmental infrastructure. After 1990, many small river basins lost their economic structure.

One of the crucial natural resources of mountain territories are fresh waters. Their quality does not only indicate the environmental condition, but also serves the indicator of civilized population. Despite favorable environment and relatively low level of anthropogenic transformation, the Karachay-Cherkess Republic has polluted river sites. The main pollutants include settlements, highways and recreation centers located on the bottom of river valleys.

Conservation and rational use of surface waters is another urgent problem. At the local level within the KarachayCherkess Republic it shall be solved with regard to a new practical direction of environmental management - nature protection of basin geosystems [2]. Thus, the priority tasks include the following: 1) to create genuinely functioning water protection zones in the most developed river valleys in order to prevent water pollution, contamination and depletion (GOST 17.1.1.01-77); 2) to ban the development of floodplains forming integral parts of rivers, which are regularly flooded [4];3) to provide settlements with modern treatment facilities.

\section{References}

[1] P.M. Lurie, V.D. Panov, Y.Y. Tkachenko. The Kuban river: hydrography and runoff regime. St. Petersburg: Gidrometeoizdat, 2005.

[2] V.L. Bondarenko, V.A. Voloshin, V.V. Gutenev, V.V. Denisov, V.P. D'yakov, A.V. Leshchenko, Y.P. Polyakov, I.S. Rumyantsev, Environmental management of basin geosystems. Textbook. Rostov $\mathrm{n} / \mathrm{D}$ : publishing center March, 2010.

[3] N.F. Reimers. Nature management. Dictionary-reference. M.: Thought, pp. 637,1990

[4] P.A. Kipkeeva, Y.Y. Potapenko, "Principal factors of sustainable tourism in the Karachai-Cherkess republic," Moscow University Bulletin. Series 5. Geography, vol. 5, pp.76-81, 2015.
[5] Our Common Future. Our Common Future World Comission on Environment and Development. Oxford New York: Oxford University Press., 1987.

[6] P.A. Kipkeeva, J.V. Volosuhin, T.V. Ivankova, Yu.Ya. Potapenko, Landscape-hydrological approach to substantiation of monitoring of river basins of mountain territories, International research journal, No. 12-1 (54), pp. 87-90, 2016.

[7] E.A. Kosolapov, A.V. Kuvakin, M.M. Mordvintsev, "Landscapehydrological approach to substantiation of monitoring and management network of small watershed." Reclamation and water management, No. 6, pp. 25-26, 1995.

[8] V.S. Revyakin, V.V. Rudskoy, "Intracontinental mountain variant of sustainable development (Altai-Sayan)." News of wounds. Series geographical, No. 6, pp. 115-122, 1998.

[9] S.V. Yasinsky, "Geoecological analysis of anthropogenic impacts on catchments of small rivers.” Izvestiya an. Series geographical, No. 4, pp. 74-82, 2000.

[10] A.G. Isachenko. Landscape science and physical-geographical zoning, Moscow: Higher school, 1991

[11] N.S. Dega, V.V. Onishchenko, H.I. Uzdenova, A.K. Shidakov, "Dynamics of the hydrochemical structure of the Kuban river in the anthropogenic zone of glacial supply of the Karachay-Cherkess Republic," Social and scientific journal Problems of regional ecology IG RAS, No. 3, pp. 92-99, 2015.

[12] V.V. Onishchenko, N.S. Dega, E.M. Baychorova, "Assessment of technogenic influence on the hydrochemical regime of the Teberda river in Karachay-Cherkessia. Safety in the technosphere." Moscow: INFRAM. vol. 3. No. 5, pp. 3-10, 2014.

[13] B.T. Konovalov, P.A. Kipkeeva, A.A. Dezhneva, Yu.Ya. Potapenko, "Climate warming in the region of Kavminvod and priority measures to prevent its negative consequences."The success of modern science, No. 8. pp. 183-187, 2016.

[14] E.V. Zaporozhchenko, "The debris problems of the upper reaches of the Malka river," Proceedings of the VI International conference Innovative technologies for the sustainable development of mountainous areas, pp. 228-229, 28-30 May 2007.

[15] A.N. Antipova, V.A. Drozdov, V.V. Kravchenko, Y.M. Semenov, O.V. Gagarinova, V.M. Plyusnin, E.G. Suvorov, V.N. Fedorov, A Winkelbrandt, V. Milken, K. fon Haaren, I. Schiller. Landscape planning: principles, methods, European and Russian experience. Irkutsk: Publishing House of the Institute of geography SB RAS, 2002. 